Original Contributions - Originalbeiträge

\title{
Herbert Fitzek
}

\section{ART moves MIND moves ART The Moses of Michelangelo and the 'Gestaltkreis' of Art Reception}

\section{Art Psychology - Formation, not Information}

Art is a highly significant subject in psychology. Nevertheless, the psychological conditions of art production and reception are still open questions. Common sense concepts of the aesthetical relation of artists and recipients are usually based on very simple transfer ideas like the engineering model by Shannon and Weaver (1949). This concept defines communication as a transport system of message containers from an information source to a receiver. In the process of communication, contents are coded by a sender and decoded by a receiver in a more or less appropriate way. According to the model, art experience is conceptualised as an information system in which creative minds generate meaningful contents and forward them to an audience by aesthetical means.

Art psychologists, starting with Sigmund Freud, have opposed technological message concepts and pointed to more complex relationships between art production and reception (in the context of psychoanalysis cp. Kris, 1952; for Gestalt theory cp. Arnheim, 2004). In aesthetical contexts, coding and decoding are not technical procedures but highly differentiated processes of generating sense. Aesthetical procedures follow a psychological structure transcending the limits of distinct intentions and can only be accurately described by a cautious hermeneutic approach.

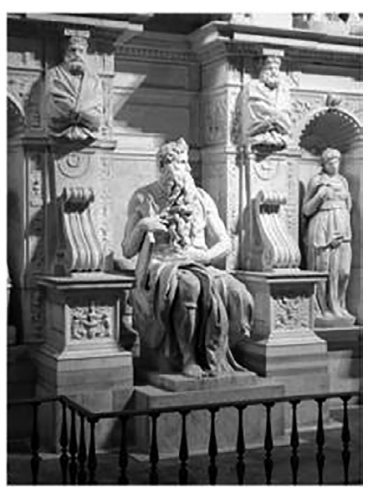

'Moses' of Michelangelo

Taking into account the complex meaning structure of art, Sigmund Freud showed that works of art are aroused by conflicts which move both artists and spectators, like the unconscious overdetermination of motherhood (love, protection and rivalry) in Leonardo's 'Virgin and Child with St. Anne' or the mixed feelings of an unavoidable death (anxiousness, longing and nemesis) in Shakespeare's 'Merchant of Venice'. The artefact that moved Freud personally more than any other work of art was the 'Moses' of Michelangelo which he repeatedly watched on his visits to Rome in the church of St. Peter in Chains on the Oppio Hill. In an anonymous study of 1913, Freud described the amazing impact he felt whenever he faced the monumental sculpture:

O Open Access. @ 2020 Herbert Fitzek, published by Sciendo. (c) BY-NC-ND This work is licensed under the Creative Commons Attribution NonCommercial-NoDerivatives 4.0 License. 
How often have I mounted the steep steps from the unlovely Corso Cavour to the lonely piazza where the deserted church stands, and have essayed to support the angry scorn of the hero's glance! Sometimes I have crept cautiously out of the half-gloom of the interior as though I myself belonged to the mob upon whom his eye is turned - the mob which can hold fast no conviction, which has neither faith nor patience, and which rejoices when it has regained its illusory idols... (Freud, 1955, 213).

Freud did not only admire Michelangelo's craftsmanship of working the huge sculpture out of Carrara marble but also found the statue so important, because it reveals a highly affective situation, exercising an overwhelming effect on visitors of all generations since the early $16^{\text {th }}$ century: 'It is the descent from Mount Sinai, where Moses has received the Tables from God, and it is the moment when he perceives that the people have meanwhile made themselves a Golden Calf and are dancing around it and rejoicing' (Freud, 1955, 216).

According to Freud's analysis, Moses is met and modelled in a culmination point of scorn and intimidation, provoked by the faithlessness of his people, and at the same time calming down this effect to a worldly wise attitude of self-restraint. Freud's analysis is striking, nevertheless, it sticks to the paradigm of message transfer with an artist coding a specific content (self-restraint of an outstanding hero) and a recipient decoding his perception into a strong message (admiration for the hero mastering his effect): 'In my opinion, what grips us so powerfully can only be the artist's intention, in so far as he has succeeded in expressing it in his work and in getting us to understand it... What he aims at is to awaken in us the same emotional attitude, the same mental constellation, as that which in him produced the impetus to create' (Freud, 1955, 212).

Since Freud's analysis a century of art psychology has passed. Regarding the meaning structure of art, plenty of models have been elaborated and a lot of artworks have been analysed. But impact models are still based on the idea of an artist's intention expressed in an artefact that manages to arouse an adequate effect in spectators. It is Freud himself who, in his study on Moses, goes beyond the narrow borders of information transfer and points to the enigmatic structure of art production and reception in the case of the unique sculpture.

\section{Art Production - MIND moves ART}

Of course, Freud could not find out what Michelangelo originally had intended by building Moses. Like most of the artists, Michelangelo did not comment on the intentions of his work. But in the case of this masterpiece of art the conditions of purchase and creation are elaborated. The sculpture was to present 
the leader of the Jewish people during its exodus from Egyptian confinement into the promised land. In doing so, it brought together a constellation of important men: the mighty Pope Julius II who purchased the famous artist Michelangelo to create the statue of the biblical hero for his commemoration and glorification.

Freud doubtlessly knew about the founding history of Michelangelo's project. Pope Julius II, an important man of the church had planned to immortalise himself by a monumental tomb which originally should have been erected in St. Peter. The dimension of papal graves in the beginning $16^{\text {th }}$ century had grown so large that a new cathedral had to be built. And the dimensions of papal power corresponded to the importance of the artist (the admired artist Michelangelo) and the significance of the motif (the hero Moses).

Julius, Michelangelo and Moses - Freud saw the origin of creating the superhuman sculpture in a psychological configuration underlying all three of them: 'It still can be asked what motives prompted the sculptor to select the figure of Moses, and a so greatly altered Moses, as an adornment to the tomb of Julius II. In the opinion of many, these motives are to be found in the character of the pope and Michelangelo's relations with him. Julius II was akin to Michelangelo in this, that he attempted great and mighty ends and especially designs in a grand scale. He was a man of action and he had a definite purpose, which was to unite Italy under the Papal supremacy. He desired to bring about single-handed what was not to happen for several centuries, and then only through the conjunction of many alien forces; and he worked alone, with impatience, in the short span of sovereignty allowed him and he used violent means. He could appreciate Michelangelo as a man of his kind, but he often made him smart under his sudden anger and his utter lack of consideration for

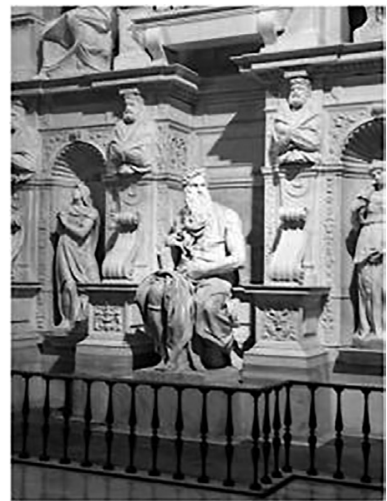

'Moses' of Michelangelo others. The artist felt the same violent force of will in himself and, as the more introspective thinker, may have had a premonition of the failure to which they were both doomed. And so he carved his Moses on the pope's tomb, not without a reproach to the dead pontiff, as a warning to himself, thus, in self-criticism, rising superior to his own nature' (Freud, 1955, 233f.).

Freud's report on the interwoven relations of the purchaser, the artist and the motif goes far beyond an artist's intention. By diving deeper into the biographies of the three men, Freud's point of view can be exceeded to a complex hermeneutic structure which comments on what Freud has impressed so much. What brings together the seemingly personal characteristics of Moses, Julius 
and Michelangelo, can be concentrated in a (non-personal) 'figuration', putting together specific traits of lives and works of the three of them. The 'figuration' term points to the almost forgotten (Gestalt psychological) position of Norbert Elias, that motivation complexes emerge from an interplay of agents who are united in a common psychological structure (Elias, 2000; Fitzek, 2000).

A first characteristic link is the extraordinary persistence of their lives. That Moses stands for long life and a life-long struggle for leading the chosen people out of Egyptian slavery is well known. Referring to the pope we find a corresponding struggle for Christian authority in politics. Appointed as a young man of 28 years by his uncle Sixtus IV, Giuliano della Rovere had been Cardinal for 32 years before being elected pope (1503-1513). Even before his death the 40 years of erecting an adequate tomb began and kept Michelangelo occupied for a long and exhausting period of his artistic life and work (1505-1545).

A second figurative aspect of the three characters is their dominant appearance and activity. Moses is famous for his continuous fight with God and his people. As a contemporary of the pope and the artist, Nicolò Machiavelli referred to the analogies of the biblical leader and the militant pope (Machiavelli, 2013). Pope Julius II was known and notorious as 'II Terrible' - the same title which was given to Michelangelo - not only expressing the fear of a strong and violent personality but also the acknowledgement for their powerful work.

Third, the almost superhuman dimensions of breaking up limits can be noticed. In the biblical exodus this process is described literally. Julius II period as a pope was occupied by nearly continuous military campaigns against Italian citizenships he dreamt of a crusade to Jerusalem and Constantinople. And Michelangelo had to lead a lifelong battle with his material which sometimes seemed to overcome his enormous power of modelling. No other artist in history is marked so adequately by the German word 'Bildhauer' as Michelangelo.

Adjacent to their going to the limit and even exceeding limits, we find in all characters a general attitude not to come to an end. Again, Moses gives first the literary evidence. In the book Exodus it is reported that Moses was to die before he could pass into the promised land. Such was the fate of Pope Julius who died before making Rome great again in Italy. He neither saw the completion of his political work nor of his tomb - nor did Michelangelo who at last had to be satisfied with the erection of a diminished version of his original plan. Originally Moses had only been one and not the central part. It is a characteristic trade of Michelangelo's work that his sculptures often do not come to an end, his style is therefore called 'non finito' (Schiff, 1959).

To exit the idea of personal similarities it can be concluded that the narrative and historical analogies of Moses, Julius II and Michelangelo build the complex of 
fragile strength. What lays the ground for the outstanding work of Michelangelo's Moses is, regardless of an artist's intention, an emerging complex which can be described in Elias' figuration terminology as the vulnerability of power (dominant appearance + breaking up limits + not coming to an end).

\section{Art Reception - ART moves MIND}

In his analysis of the Moses of Michelangelo, Freud concentrates his interest on the impact of this impressive constellation. As an originally anonymous spectator Freud makes himself one of the nameless visitors getting under the eyes of the huge sculpture.

Freud was aware of the strong impression which Moses exercised on him since his early youth and which even got stronger in his experience of life. Since the days of his childhood Freud admired the Jewish hero as a religious and paternal leader. His powerful appearance seemed to be as much important as his sensitive and even assailable traits. Last but not least, from his self-analysis, it is known that Freud was convinced of his mission of a new and adventurous intellectual movement. And like the historic Moses he considered himself as a leader guiding his people out of the Egyptian exile of academic tradition into a new and promising concept of science (Grubrich-Simitis, 2004).

Freud himself explicitly drew this comparison; on a postcard to S. Ferenczi he openly alluded to the identification. While the psychoanalytical movement grew in the first decade of the $20^{\text {th }}$ century, Freud felt more and more involved in a leadership position, at last handing over the lead to a dignified successor, C. G. Jung, whom he appointed as his 'Joshua': 'If I am Moses, you are the Joshua and will take possession of the promised land of psychiatry' (Freud and Jung, 1974, 218). But like Moses, Freud had to face the faithlessness of his chosen people when being confronted with the treason of the most hopeful of his disciples. When writing down his analysis in 1913, Jung had started to criticise Freud's concepts in his Zurich circle and to develop an own deviant concept of depth psychology. Freud was horrified by this concept as much as Moses had been, when facing the golden calf after his return from Mount Sinai.

As a recipient, Freud proves to be implicated in the same figuration as the personage of art production. Again, it is the ambivalence of power and vulnerability that characterises Freud's approach. It seems to be this ambivalent identification in leadership that arouses a strong impact on the founder of psychoanalysis. In his inner correspondence of the years 1912 and 1913, Freud had to face a dangerous period in the psychoanalytic movement, not yet knowing if he should draw the consequence and break with the hopeful successor or if he should sagely master 
his rage and look for a painful compromise. In this uncomfortable situation the multivalent constellation of the Moses motif is condensed to a doubtless message:

What we see before us is not the inception of a violent action but the remains of a movement that has already taken place. In his first transport of fury, Moses desired to act, to spring up and take vengeance and forget the Tables; but he has overcome the temptation, and he will now remain seated and still, in his frozen wrath and in his pain mingled with contempt. Nor will he throw away the Tables so that they will break on the stones, for it is on their especial account that he has controlled his anger; it was to preserve them that he kept his passion in check. (Freud, 1955, 229f.).

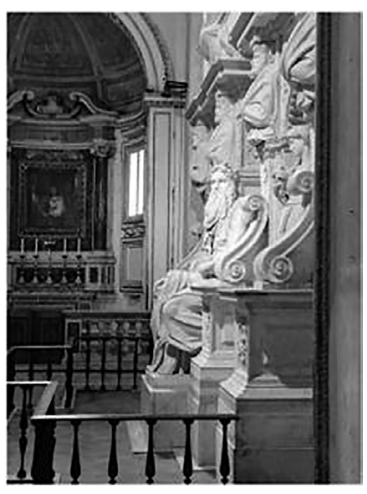

'Moses' of Michelangelo

For Freud this Moses is an icon of self-restraint in a highly troubled situation, thus answering his mood of doubt and anger. The ambiguous state of mind of descending from God in perfect serenity and at the same time coming across humiliation and treason is densified in a distinct statement: not to give up his countenance and instead beware self-control.

As a scientific author, Freud shortens the range of interpretation. For him the variety of ambivalent meanings is contracted to the version of controlled force. The whole scope of visible sentiments in this Moses - dignity, doubt, anger, outburst and desperation - is set aside in the one-dimensional solution of self-restraint. Nevertheless, different interpretations can be noticed in the long chain of experts before and after Freud as well as in the twofold report of the biblical exodus. It is the same Moses who now shows divine brightness and then satanic fury, who now cools down his effect and then acts out his anger, who carefully negotiates with God to pardon his people and some verses later executes every tenth Israelite regardless of being guilty or not guilty.

Being subjected to his identification, Freud may have cut the complex structure of the Moses of Michelangelo to a decisive end. As an anonymous spectator, however, Freud can serve as an example of how the impact of the sculpture shifts from an individual perspective. Under the conditions of the whole figuration, Freud, as an anonymous visitor, develops a reception concept that is dominant for him and fits his temperament. As a nameless spectator, Freud turns out to be an example of the psychological fact that recipients do not claim on the thorough constellation but pick out a specific aspect, referring to what is meaningful for them and what finds access to their situation. The art reception is, so to say, the transformation of common figurations to personal constellations of meaning. The power of art, therefore, is not limited to a shifting individuality, but it is 
fostered by personal perspectives. Individuals need works of art to stimulate personal complexes; conversely, the works of art need personal complexes to unfold their significant effects.

For our project of 'art coaching' (Fitzek, 2013), we use the exchange of general motif and personal perspective in the context of workshop settings in which we systematically use art reception as a key for processes of self-experience. We have been visiting the Moses statue in Rome for 20 years with hundreds of visitors. As an example, we conduct leadership workshops based on the Moses experience in the context of business psychology. Our training with groups of five or six managers starts with an unbiased approach to St Peter in Chains for half an hour and go on with reflections on the personal perspectives on Moses. Gradually, the participants get aware of the range of approaches and of how the different perspectives stimulate each other and encourage motion in attitude and interpretation. In three-day workshops the managers profit from the overdetermination of aesthetic perception. Accompanied by a well-experienced coach they proceed from the insights in the common figuration to personal solutions that this Moses provides for their self-concept in work and life.

Facing the Moses of Michelangelo, less prominent leaders than Freud make very similar observations and notice the moments of strength and power besides the expressions of weakness and desperation. In the reflecting groups they collect their points of view and learn to accept different positions as equivalent approaches to Moses and leadership experience. Those who are affected by the anxious expression of Moses turned to notice the hard face of power. Those who are stressed by the fierce nature of leadership come across the charisma of power. In commonly finding out the whole range of the Moses figuration, the coaching groups acknowledge that strength and weakness of empowerment are inseparably entangled and to be managed in finding one's position. Students whom we guide to the Moses do not focus on leadership issues that much. Their experience is much more focussed on what leads through their actual lives and conflicts, their family constellation, their interest in finding a fitting education and profession.

\section{MIND moves ART moves MIND - Moses and the 'Gestaltkreis' of Art Reception}

After all, it should be stated that the simple logic of information transfer cannot adequately be applicated in psychology of art production and art reception: at least this Moses does not correspond to the model of message transfer with a sender who packs a code into an artefact by aesthetical means which is unpacked by a well-informed recipient.

According to the figuration concept, artworks are constituted in a complex meaning structure that is responsible for the creation and the perception of the work and which opens up a field of exchange between the subjects and objects 
of art. An adequate concept of art psychology thus should focus on this field structure which is not emerging from the personal minds of artists or recipients but ties together all participants in a formative process of producing sense. This structure does not appear clearly and comprehensively, it can be elaborated using a careful, thick description in the conditions of art productions as well as in the reception processes of the spectators. According to the source of motion, it can be characterised as a mutual impulse from mind to art (art production) and from art to mind (art reception).

Mind moves art, and art moves mind. This is no metaphoric expression, it can be observed in a very literal way at the Moses in San Pietro in Vincoli. Not that the fight of Michelangelo with the Carrara marble is to be noticed in a literal sense, but the intimidating effect of the statue on the spectators is openly manifested in their search for an adequate position in space as Freud had described in the introducing sentences of his study. Under the eyes of the monumental marble sculpture the recipients take a position in front of the statue or shift from left to right or from right to left. They step back behind the shelter of columns or the superstructure of the altar room. They are moved through the church or freezed in a fixed observing position.

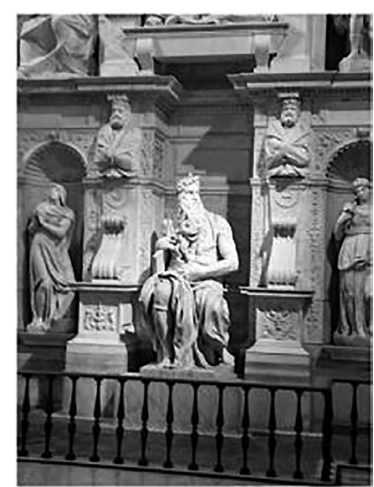

'Moses' of Michelangelo

To find one's position facing the superhuman Moses, however, is only one part of the motion. A complimentary motion goes out of the spectators and seems to move the sculpture by changing perspectives. Spectators often comment on totally different impacts depending on their movement towards the statue. Different positions in space generate different aspects of meaning. Focussing Moses from left to right, the recipients first notice a well-balanced, a rather distant appearance that more and more is irritated when coming to the fore and entering his glimpse. Now the figure seems to stand up, wide-eyed and fraught or even frightened, before it sinks into its sit from an utterly right observing position. If they surround the statue from the right side an intimidated person is to be seen who seems to work out himself from his seat and fix the spectator angrily. Moving on, the statue seems to settle gradually and calm down itself up to the position where Moses gets back his aloof position.

The workshops with recipients show the interplay of motion on the side of the spectators (walking around) as well as on the side of the work of art (seemingly turning around). Subjects and objects seem to generate a shifting interrelation and, by that, reveal characteristic points of view - in a very literal sense and about each other. As the sculpture seems to be stopped or moved by the spectators' 
approach, this approach is stopped and moved by the sculpture's changing appearance. It should be possible to express this characteristic intertwining of watching and moving in terms of Gestalt psychology.

The interplay of motion and perception reminds to an observation which has been made nearly 80 years ago by a German neurologist who worked on the genesis of perception and who found a hidden interdependence with shifts in the observing position. I take the opportunity to refer to Victor von Weizsäcker's famous, but almost forgotten idea of a Gestalt circle ('Gestaltkreis') of action and perception. Weizsäcker pointed to their relationship as to mutual concealment of watching and acting in human orientation.

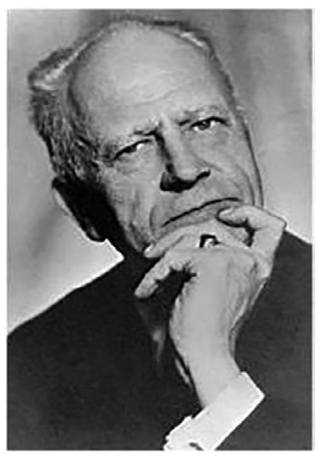

Viktor von Weizsäcker (1886-1957)

According to Weizsäcker both functions are constitutive for human behaviour but hidden against each other like the ins and outs in a revolving door ('Drehtürprinzip'). Weizsäcker's Gestalt idea has not fully been appreciated by Wolfgang Metzger and therefore may not have been adopted in Gestalt theory (Zybowski, 2009, 267ff.). Nevertheless, I find it important to remind Gestalt theory - and Gestalt theorists - to this prominent researcher on the holistic character of human nature and behaviour. Especially in the context of 'motion' Gestalt theory could profit from his idea of identifying acting and perceiving in a corresponding unity like in the wellknown reversible figures ('Kippfigur'): '(...) das Wesentliche des Gestaltkreises ist, dass das Wahrnehmen und das Bewegen einander vertretbare Zustände in jedem biologischen Akt sind, dass sie jeweils gegeneinander verborgen bleiben und dass an dieser Verschränkung, Vertretung und Verborgenheit auch das Subjekt und Objekt teilnehmen: das, Wirkliche' erscheint bald im einen, bald im anderen' (Weizsäcker, 1940, 93).

In Gestalt psychology of art, the concealed reversibility of acting and perceiving opens the door to a better understanding of the interplay of fixing and shifting in action and perception. The same correspondence may organise art perception as an exchange of object aspects and subjective approach. My academic teacher, Wilhelm Salber, showed the correspondence of figurative aspects in works and percepts of art in experimental studies on art experience more than sixty years ago (Salber, 1957). According to Weizsäcker's ideas, Salber expressed the complementarity of art approach and art reception in the analogies of image patterns and patterns of experience ('Bildgefüge und Erlebnisgefüge').

Referring to the idea of a 'Gestaltkreis' subject and object, artefact and recipient, are not separated but linked in a common creation of psychological reality. Psychological reality does not come from an 'inner world'. It marks a continual 
process of creating subjective realities out of material artefacts and of creating objective reality by mental experience. Aesthetical experience thus highlights the interplay (Salber: 'Zwischenreich') of subject and object most clearly and therefore also builds a solid ground for developing psychological research in an application field of coaching and counselling. For this purpose - that of art coaching and art counselling - I would like to adjust my description of the interrelation of art and mind in respect to the title of my contribution: ART moves MIND moves ART - as a 'Gestaltkreis' of Art Reception

\section{Summary}

According to Gestalt theory the impact of arts is not adequately described as a transfer of an artist's message into a recipient's state of mind. As a matter of fact (and effect) art represents complex fields of meaning (figurations) rooting in the specific conditions of art creation and proceeding to the concrete effects of art reception. From a psychological point of view artefacts cannot be reduced to static objects, nor are the recipients to be seen as passive spectators of the scenery. Aesthetical experience is an action field from which the material of art and its reception emerge. In my contribution the relationship of subject and object in art is modelled in terms of Victor von Weizsäcker's Gestaltkreis of perception and action. For this purpose, I will refer to the favourite subject of art coaching: the Moses of Michelangelo in Rome.

Keywords: art psychology, art coaching, figuration, Gestalt circle.

\section{ART moves MIND moves ART Der Moses von Michelangelo und der "Gestaltkreis" der Kunst-Rezeption}

\section{Zusammenfassung}

Aus gestaltpsychologischer Sicht geht das Erleben von Kunst nicht auf im Transfer von künstlerischem Ausdruck in Rezeptionswirkung. Tatsächlich (und wirkungspsychologisch) repräsentieren Kunstwerke komplexe Bedeutungsfelder (Figurationen), aus deren Wirken kunstvolle Produktionen hervorgehen und als deren Wirken Rezeptionsprozesse beschrieben werden können. Vom psychologischen Standpunkt aus können Werke nicht auf statische Objekte reduziert werden und Betrachter nicht auf passive Beobachter. Ästhetische Erfahrung ist ein Aktionsfeld, aus dem Kunst hervorgeht und erlebbar wird. In meinem Beitrag wird das Verhältnis von Subjekt und Objekt im Kunstgeschehen nach Victor von Weizsäckers Idee des Gestaltkreises von Wahrnehmung und Beobachtung modelliert - am Beispiel des Moses von Michelangelo, der gleichzeitig Grundlage für die Entwicklung von Kunstcoaching geworden ist.

Schlüsselwörter: Kunstpsychologie, Kunstcoaching, Bedeutungsfelder, Gestaltkreis.

\section{References}

Arnheim, R. (2004). Visual thinking. Berkeley, CA: University of California Press.

Elias, N. (2000). The civilizing process. Oxford, UK: Blackwell.

Fitzek, H. (2000). Figurations in everyday life - A research program of cultural psychology. Forum Qualitative Social Research, 1(2). doi: 10.17169/fqs-1.2.1077

Fitzek, H. (2013). Artcoaching. Gestalt theory in arts and culture. Gestalt Theory, 35(1), 33-46. 
Freud, S. (1955). The Moses of Michelangelo. In S. Freud (Ed.), Standard edition (Vol. XIII, pp. 210-238). London, UK: Hogarth.

Freud, S. \& Jung, C. G. (1974). Briefwechsel. Frankfurt, Germany: Fischer.

Grubrich-Simitis, I. (2004). Michelangelos Moses und Freuds "Wagstück". Eine Collage. Frankfurt, Germany: Fischer.

Kris, E. (1952). Psychoanalytic explorations in art. New York, NY: International Universities Press.

Machiavelli, N. (2013). The prince. Scotts Valley, CA: Create Space Independent Publishing.

Salber, W. (1957). Bildgefüge und Erlebnisgefüge. Jahrbuch für Psychologie, Psychotherapie und medizinische Anthropologie, 5(1/2), 72-81.

Schiff, G. (1959). Das "non finito" bei Michelangelo und im Manierismus. Du: kulturelle Monatsschrift, 19, 29-30.

Shannon, C. \& Weaver, W. (1949). A Mathematical Model of Communication. Urbana, IL: University of Illinois Press.

Weizsäcker, V. V. (1940). Der Gestaltkreis. Theorie der Einheit von Wahrnehmen und Bewegen. Leipzig, Germany: Thieme.

Zybowski, P. (2009). Rezensions- und Rezeptionsgeschichte zu "Der Gestaltkreis. Theorie der Einheit von Wahrnehmen und Bewegen" von Viktor von Weizsäcker (dissertation), Berlin.

Prof. Dr. Herbert Fitzek, Vice-Rector for research at the BSP Business School, Berlin, business psychologist and cultural psychologist, psychotherapeut, coach and organisational counsellor. He has to his credit 10 monographs and several congress publications, articles and book chapters referring to Gestalt and cultural psychology, morphological psychology, and the theory and practice of art coaching

Address: BSP Business School Berlin - Hochschule für Management, Siemens Villa, Calandrellistraße 1-9, 12247 Berlin, Germany.

E-mail: herbert.fitzek@businessschool-berlin.de 